Available online at website :

http:/ /e-journal.adpgmiindonesia.com/index.php/jmie

JMIE: Journal of Madrasah Ibtidaiyah Education, 4(1), 2020, 1-21

\title{
THE MODEL OF GROW ME FOR DEVELOPING CHILD FRIENDLY SCHOOL
}

\author{
Zaenul Slam \\ Universitas Islam Negeri (UIN) Syarif Hidayatullah Jakarta \\ Email: zaenul_slam@uinjkt.ac.id
}

Naskah diterima : 29 Desember 2019, direvisi : 1 Maret 2020, disetujui : 1 April 2020

\begin{abstract}
This study is aimed to know the model of GROW ME for developing Child Friendly School (CFS). Currently, incidents of violence against students still occur even at low level such as teacher disiplines students who have not done homework by standing in fron of the class or students make funny remark each other. This is because schools have not been optimally implementing CFS yet. To overcome the problems, this study used a model of GROW ME. It is applied to develop CFS, both in their planning aspects and in their implementation aspects. The method of the research was school action research. It was consisted of two cycle, and each cycle consisted of four activities, namely: planning, action, observation, and reflection. Data was collected by using a sheet instrument of monitoring and evaluation for CFS to obtain pictures achievement in developing of CFS. Data nalysis from pictures achievement in development of CFS was made in a percentage value. Based on the results of quantitative analysis: First, the planning dimension obtained an average value of $80 \%$ (good category) in cycle 1 and 90\% (very good category) in cycle 2. Second, the implementation dimension obtained an average of $80,82 \%$ (good category) in cycle 1, and 90\% (very good category) in cycle 2. This shows that there are significant differences in increasing of CFS in both the planning and the implementation dimensions of cycle 1 and cycle 2 .
\end{abstract}

Keywords: model, grow me, developing, child friendly school

Pengutipan: . Slam, Zaenul. (2020). The Model of Grow Me for Developing Child Friendly School. JMIE: Journal of Madrasah Ibtidaiyah Education,4(1), 1-21. jmie.v4i1.167. 


\section{INTRODUCTION}

Schools have a strategic role as the vital child friendly educators when the child friendly education in society become weak. Therefore, schools have already had a broad foundation and support to develop the Child Friendly School (CFS). It is a vehicle for guaranteeing and fulfilling children's rights in every aspect of their life so that students will feel safe and comfortable being in school and also achieve to a success then parents will feel calm.

However, it is not the same with the real condition. The reality that exists in some schools precisely shows the current situation and condition of the school is a prison for students (Tilaar, 2002: 326). Even in some schools often used as an arena of violence against students (Winataputera, 2012: 2). As a result, children's education in several schools currently stumbles upon a variety of violent problems.

As in the national scale, there have been a variety of violent events in schools recently which were conducted by teachers with a frequency of 2039 cases $(29.9 \%)$, classmates with a frequency of 2871 cases (42.1\%), and other frequency classmates with 1902 cases $(27,39 \%)$ (KPAI: 2013). It also seems that a variety of violent incidents sometimes occur in schools conducted by some teachers with the reason to disipline students such as teacher asks students to stand or squat in front of the class because they do not do their home work, or asks them to stand in the ceremonial field who are late for class or not fully dressed. In addition, the act of tweaking, pinching, calling names by other bad nicknames, teasing, mocking, making fun, telling others to do something that is not obscene, and physical assault (hitting, kicking, and spiting) some times also occur in schools conducted by number of students to the other students.

Based on the explanation of the violence in schools as an educational issue above, schools should be a vehicle for cultivating the principle of safe, comfortable and peacefull. Therefore, the prevention must be done throughly. This is actually the mandate of the 1945 Constitution of the Republic of Indonesia Article C states that: everyone has the right to develop themselves through meeting basic needs, has the right to receive education and benefit from science and tecnology, arts and culture, in order to improve quality his life and for the welfare of humanity.

Article 28B (2) of the 1945 Constitution states that: "every child has the right to survival, growth and development and is entitled to protection from violence and discrimination. These provisions are operationally regulated in Article 54 of the Child Protection Act, which states that "Children in and within the school environment must be protected from acts of violence committed by teachers, school managers or their friends in the school concerned, or other educational institutions. Article 70 Paragraph (2) states that: everyone is prohibited from treating children by ignoring their views in a discriminatory manner, including labeling and equalizing education for children with disabilities. In the 
Minister of Education and Culture regulation number 82 of 2015 concerning prevention and management of violence in the educational unit environment. This regulation is the state must be present to provide protection to children, as well as intervene in violence.By this Minister of Education and Culture Regulations, school must be fun places for children, like they are in park. Children will certainly feel at home in schoool.

Regarding to the regulations and the violence problem above, school should be a vehicle for free learning. Freedom of learning is not freedom that is too far, but freedom that follows the order and peace of life together in school, but the quality of the whole school must be improved too. If the acces and the quality of education can be implemented, children who study at elementary school can reach the goal of teaching and learning programand continue to middle school (Prmata, 317: 2017). On of the possible programs which can be improved the quality education in the schho is Child Friendly Schhol.

A Child Friendly School (CFS) is a school that recognizes and nurtures the achievement of children's basic right. The CFS works with all commitmen-holders, especialy parents/guardians of student, and values the many kinds contributions they can make in seeking all children to go to school, in the development of a learning environment for children and effective learning quality according to the children's current and future needs. The learning environment of Child Friendly School ara characterrized by equity, balance, healt. These led to the developmentof knowledge, skills, attitudes values, morals so that children can live togethger in a harmonious way. A Child Friendly School (CFS) nurtures a schools friendly child, support children for development and a school-friendly community (Akoto Mark, 2013). UNICEF also said that CFS model purpose is to move the systems of schools anf education progressvevely into standars of quality, addressing kinds of elements which impact to the well-being and children's right as a leaner and theteaching prior beneficiary while improving the funtion of school in the process. Therefore, children friendly school concept is an integrated holistic system, a systemwide approach for improving the quality of education which places children as the education reform center (Cobanoglu et al, 2018: 467). CFS is school capable of providing a guarantee, fulfillmen, respect for children's rights and children protection from all acts of violence, discrimination, and other mistreatment and support child participation in planning, implementing and evaluating policy in education unit (Regulation of the Minister of State for the Empowerment of Women and the Protection of Children of the Republic Indonesia Number 8 of 2014).

A Child Friendly School (CFS) also must be able to guarantee, provide and respect the child rights protection against violence, discrimination, and violence, as well as to bolster children participation in planning, policy, and study and complaints mechanism (Hermino, 2016). The development of CFS is a need to guarantee and fulfill children's rights in every aspect of life so that students will feel safe and comfortable in school and excel and parents 
feel calm. As stated by Tilaar (2002: 327) that education is actually the liberation of the magma of each individual in order to obtain the right direction given by the environment, leadership, and guidance of educators with a dear kasis dear. Ki Hadjar Dewantara explained that education is an effort to advance the growth of character, mind, and body of children. These parts must not be separated so that we can advance the perfection of life (Ministry of Education and Culture, 2016).

A Child Friendly School aim to protect and provide services that guarantee and protect children from physical and non-physical abuse (Subur, 2017: 1). The purpose of a model of Child Friendly School is to move schools and education systems progssively towards quality standars, addressing all elements that influence the wellbeing and rights of the child as a leaner and the main beneficiary of teaching, while improving other school functions in the process (UNICEF, 2009: 2). Quality standars should make it possible for all children to acces school, survive from grade to grade and complete the cycle on time; they should also provide an enriched educational experience through which student can thrive, develop and achieve their full potential. To this end, the models of CFS are concerned with harnessing the full involvement and support of all parties in a position to facilitate children's right to a quality education. The parties, or 'duty bearer', include parents, communities, teachers, principle, education planner and civil society groups, as well as local and national goverments and their external partners. Their involvement enable schools and education systems to provide the conditions and resources necessary for achieving the quality standars CFS models envision.

In order to overcome the problems of children's education and also development CFS, one of the possible models which can be used for development of CFS is coaching. Coaching is the process of estoring or asisting teachers who are fostered from current conditions to better conditions according to their needs. Hayes in Ministry of Education and Culture (2014: 115) explains that: " coaching is the key to success in a managemet process, because coaching brings people to always contribute and participate as active parners". The model of GROW ME (Goals (G). Reality (R), Option (O), What Nek (W), Monitoring (M), Evaluation (E). The models of GROW ME is a professional development philosophy and is a tool to encourage coaching and improve performance based on in creasing self-awareness and personal quality. By using coaching has the following advantages: (a) Spur cooperation (in team coaching); (b) facilitating leaners to get new skills; (c) make everyone to share knowledge, skill and experience (team coaching); (d) bridging the gap between theory and practice; (e) can be delivered in aformal (structured) or informal way. Hen two-way interaction; ( $f$ ) the relationship between coaches and learners is a partnership; (g) focus on how to work better; (h) the relationship between coach and coachee is based on tust and respect (Ministry of Education and Culture, 2013). 
This study is aimed to know the model of GROW ME for developing Child Friendly School.

\section{RESEARCH METHODS}

The research method applied in this research was School Action Research. School Action Research (SAR) is a research that begins with school problems, completed through specific actions of the researchers' ideas to overcome school problems (Ministry of National Education, 2009: 9). The research was done in 2 cycles. The cycles included planning, implementing, observasing and reflecting.

The research was conducted at SD Negeri Cijati 1, Majalengka Regency in 2019. The school has a principle and 24 teachers. The research was done in that school because it was as one of the Child Friendly School (CFS) in the Regency, but the school has not implemented it optimumly yet.

In this study, there were several factors that will be examined in the development of CFS. They were: (a) the police of CFS, (b) program and facilities of health in school, (c) environment and infrastructure that are safe, comfortable, healthy, clean, and accessible that meets SNI construction and buildings, (d) children's participation, (e) planting noble values and cultural arts, (f) educators and trained education staff, (g) safety program in school, (h) community and business community participation in school.

Data collection techniques of this study were: (1) qualitative, the data obtained from interviews and the fieldnotes of direct observations, (2) quantitative, the data obtained from assessment of monitoring and evaluation result of CFS implementation.

The data obtained were analyzed by referring to the analysis technique that is the interpretation of the observational data. The results of the analysis was got from the implementation of CFS through the Model Of GROW ME.

Data analysis were from: (1) indicator of data CFS; (2) data of interview and note of observer field.

\section{RESULTS AND DISCUSSION.}

Research result

Cycle 1

1. Planning

In the first cycle, the researcher collaborated with the Team of CFS to carry out the planning activities for the action CFS through model of GROW ME. These activities include: (a) preparing CFS, (b) preparing Power point, material CFS, (c) compiling the participant 
observation participant activation instrument, (d) developing instruments of monitoring for evaluating the implementation of the CFS.

Table 1. Planning Child Friendly School (CFS) in Cycle 1

\begin{tabular}{|c|c|c|c|c|}
\hline \multirow{3}{*}{ No } & \multirow{3}{*}{ Component } & \multicolumn{3}{|c|}{ Average $\quad \%$} \\
\hline & & \multicolumn{2}{|c|}{ Suitability } & \multirow[t]{2}{*}{ Category } \\
\hline & & Yes & No & \\
\hline 1 & Development planning CFS & $80 \%$ & $20 \%$ & Good \\
\hline 2 & Using power point of CFS & $80 \%$ & $20 \%$ & Good \\
\hline 3 & $\begin{array}{l}\text { Instrument observation of the activation } \\
\text { participans CFS }\end{array}$ & $80 \%$ & $20 \%$ & Good \\
\hline \multirow[t]{3}{*}{4.} & $\begin{array}{l}\text { Instrument monitoring evaluating the } \\
\text { growth CFS. }\end{array}$ & $80 \%$ & $20 \%$ & Good \\
\hline & Total & 320 & & \\
\hline & Average & 80 & & Good \\
\hline
\end{tabular}

Based on table 1 the results from the first cycle of research in planning obtained by the following figure 1.

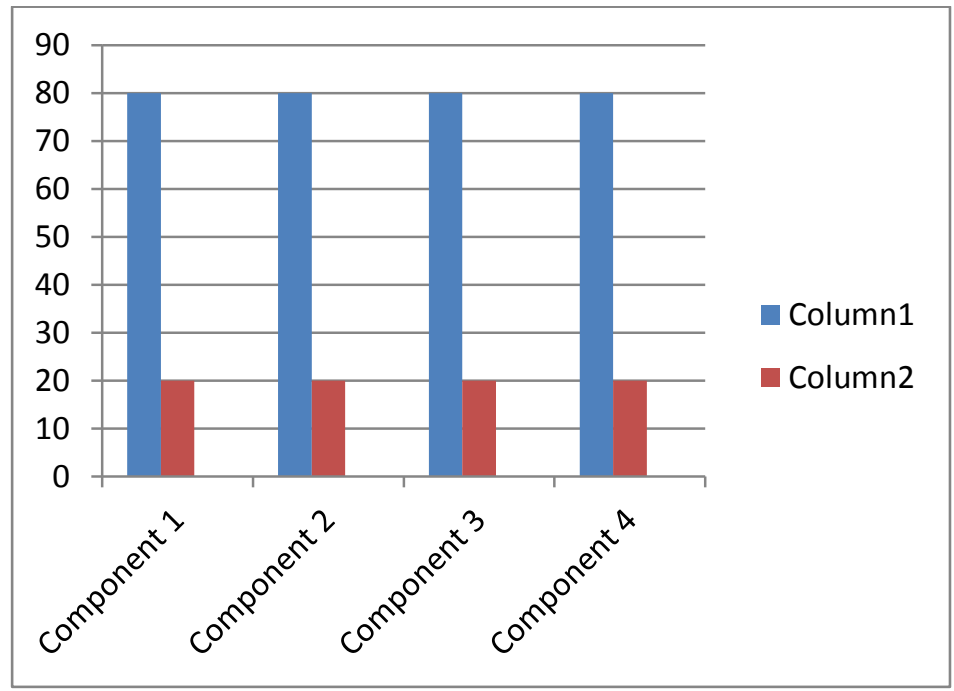

Figure 1. Planning of Child Friendly School in Cycle 1 
Graph Description:

Component 1 = The development planning CFS

Component $2=$ The powerpoint CFS

Component $3=$ The instrument of observation of the activation participans CFS

Component $4=$ The instrument of monitoring evaluating the growth of CFS

Note: A (Very Good) = 86-100
$\mathrm{B}(\mathrm{Good})=71-85$
$\mathrm{C}($ Enough $)=56-70$
$\mathrm{D}($ Less $)=\leq 56$

\section{Action}

The implementation of the first cycle, researchers collaborated with the CFS Development Team to assist in the implementation of the CFS through the model of GROW ME in accordance with the compiled Program Plan, namely preliminary activities, core activities, and closing activities. The following is a description of the steps to accompany the CFS with the model of GROW ME.

\section{a. Preliminary activities}

Preliminary activities, first, the coach as a researcher greets and prays together and checks the readiness of the participants/coachees for physical and psychological assistance. Researchers submit questions and answers (apperception) material for CFS. The researcher reminded the purpose of assisting in the implementation of the CFS, and the outline of the scope of the material as well as an explanation of the activities and assessment system that will be carried out by the trainee in the mentoring. Then the researchers asked participants to sit in their groups.

\section{b. Core activities}

In the core activities, the first activity determines the Goals $(G)$ objectives of implementing the CFS. First, the coachee discusses the objectives of the implementation session of the CFS. Coachee / participants agreed that this session aims to make participants understand the definition of CFS, indicators of CFS, CFS stages, and CFS activities. Next the coach asks about goals, meanings, and indicators of success to the goal. 
Secondly, the implementation of Reality (R), the activities are: (a) the coachee/ participant evaluates himself about the implementation of the CFS, what is the current condition, and why. (b) The Coach asks about the conditions and reasons, and the efforts that have been made. As stated by the Principal that the current condition is related to the implementation of the CFS, the school is actually starting to implement the CFS. (1) the school starts to socialize the "Slogan" that the school is an area of the CFS. Furthermore, the school rules are also published on things that must be done by school residents such as manners and things that should not be done such as tweaking, pinching, shouting. compare with other friends. (2), the school begins to carry out various activities towards CFS such as (a) physical arrangement, such as the arrangement of the school location, arrangement of the study room, arrangement of the laboratory room, arrangement of the library room, arrangement of the counseling room, arrangement of the happy corner where the child expresses himself, confide in, and playing with peers, structuring healthy canteen and honest canteen, arranging trash cans, arranging toilet. (b) fostering trained and professional teachers and administration through school In House Training and sending training to the Education Office. About the importance of the implementation of the the CFS according to the teacher class 6 that schools need to consciously endeavor to guarantee and fulfill children's rights in every aspect of life in a planned and responsible manner so that children are safe. comfortable, conducive to be in school.

Third, the implementation of Options (O) alternative. the activities are: (a) the trainer asks himself about solutions to achieve the goals, according to english teacher there needs to be a stage towards CFS which includes preparation of planning, implementation, and monitoring of evaluations. Next the coach asks the coachee to explore various other alternatives and offer suggestions carefully. Fourth, the implementation of What's Next? / Will (W). In the implementation of What's Next? (W), the activities are: (1) The Coachee reveals alternative plans for solving the problem following the stages, as well as potential obstacles and solutions, as well as time allocation. Stages towards CFS include: First, Preparation, (a) it is necessary to conduct a child consultation to map the fulfillment of rights and make recommendations made by the Guidance and Counseling teacher, (b) Principal, School Committee, Parents/Guardians, and Students Committed to developing CFS. This commitment takes the form of a CFS policy. (c) the Principal together with the School Committee, and students to form a CFS development team. This team is tasked with coordinating various efforts of the developer. 
Tabel 2. The Result of Monitoring and Evaluation from Coach and Coachee of the CFS in Cycle 1

\begin{tabular}{|c|c|c|c|c|}
\hline \multirow[t]{2}{*}{ No } & \multirow[t]{2}{*}{ Component } & \multicolumn{2}{|c|}{$\begin{array}{l}\text { Average Achievement } \\
\text { Percentage } \\
\%\end{array}$} & \multirow[t]{2}{*}{ Catagory } \\
\hline & & Yes & No & \\
\hline 1. & The policies of school regarding CFS. & $80 \%$ & $20 \%$ & Good \\
\hline 2. & $\begin{array}{l}\text { The programs of health and facilities in } \\
\text { education units }\end{array}$ & $80 \%$ & $20 \%$ & Good \\
\hline 3. & $\begin{array}{l}\text { The environment and infrastructure are safe, } \\
\text { comfortable, healthy, and clean, as well as } \\
\text { accessible to meet SNI construction and } \\
\text { buildings. }\end{array}$ & $90 \%$ & $10 \%$ & Very good \\
\hline 4. & The existence of child participation & $80 \%$ & $20 \%$ & Good \\
\hline 5. & $\begin{array}{l}\text { The cultivation of noble values and cultural } \\
\text { arts }\end{array}$ & $90 \%$ & $10 \%$ & Very Good \\
\hline 6. & $\begin{array}{l}\text { The availability of trained educators and } \\
\text { education personnel }\end{array}$ & $80 \%$ & $20 \%$ & Good \\
\hline 7. & The safety program in the education unit & $80 \%$ & $20 \%$ & Good \\
\hline 8. & $\begin{array}{l}\text { The role of community and business } \\
\text { participation in the education unit }\end{array}$ & $80 \%$ & $20 \%$ & Good \\
\hline & Total & 660 & 140 & \\
\hline & Average & 80,82 & 19,18 & \\
\hline
\end{tabular}

Note: A (Very Good) $=86-100$

$\mathrm{B}(\mathrm{Good})=71-85$

$\mathrm{C}($ Enough $)=56-70$

$\mathrm{D}($ Less $)=\leq 56$

Based on table 2 about the results of monitoring the evaluation of the coach and coachee about the Implementation of CFS in the Cycle 1 obtained by the following figure 2. 


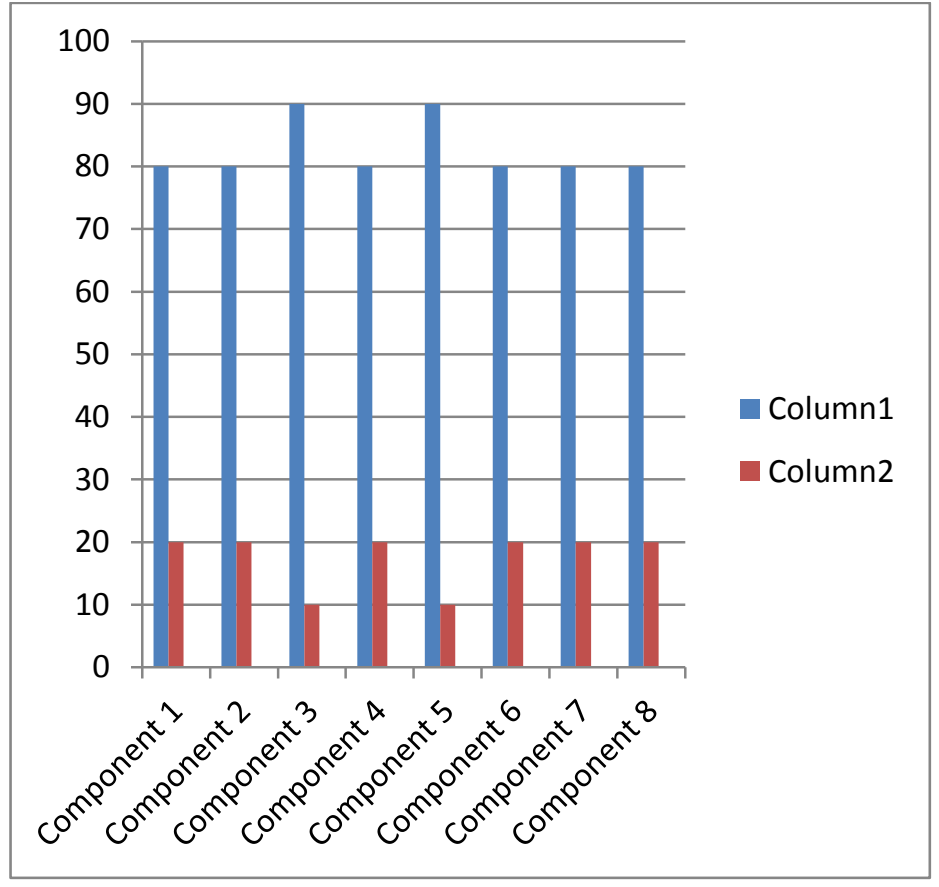

Figure2. Implementation of the Child Friendly School (CFS) in Cycle 1

Information:

Component 1 = The policies of school regarding CFS

Component $2=$ The programs of health and facilities in education units.

Component 3 = The environment and infrastructure that are safe, comfortable, healthy, and clean, as well as accessible to meet SNI construction and buildings.

Component $4=$ The existence of child participation

Component $5=$ The cultivation of noble values and cultural arts

Component $6=$ The availability of trained educators and education personnel

Component $7=$ The safety program in the education unit

Component $8=$ The role of community and business participation in the education unit

\section{Observation}

The mentoring observation activities carried out by the coach / researcher aimed at various performances of the school/coachee residents during the first cycle of mentoring activities. 
Based on the field notes during the implementation CFS by program mentoring, the observer found that in the implementation of mentoring most of the trainees were active, cooperating, and resilient, and still a small portion of the trainees seemed hesitant, and less active.

\section{Reflection}

The results of reflection in the first cycle show that: (a) how to provide motivation for participants at the beginning of assistance is still conventional. It is necessary to think about how to arouse the interest of participants/coachees so that they are optimally interested in the material and process CFS; (b) The coachee's appearance in the implementation CFS using the model of GROW ME This model is still not optimal so there needs to be a further cycle in the implementation CFS.

\section{Cycle 2}

\section{Planning}

In the second cycle, researchers consistently collaborated with the team of CFS to carry out activities to improve mentoring planning CFS through the model of GROW ME. These activities include (a) reviewing the plan on the implementation CFS, (b) refining the power point material CFS, (c) reviewing the observation instrument of the activation of the mentoring participants CFS, (d) reviewing the monitoring evaluation instrument implementation CFS.

Table 3. The Planning of the Child Friendly School (CFS) in Cycle 2

\begin{tabular}{|c|c|c|c|c|}
\hline \multirow[t]{2}{*}{ No } & \multirow[t]{2}{*}{ Category } & \multicolumn{2}{|c|}{$\begin{array}{l}\text { Average } \\
\text { Suitability }\end{array}$} & \multirow[t]{2}{*}{ Category } \\
\hline & & Yes & No & \\
\hline 1 & Development planning CFS & $90 \%$ & $10 \%$ & Very good \\
\hline 2 & A power point CFS & $100 \%$ & - & \\
\hline 3 & $\begin{array}{l}\text { Instrument of observation of the activation } \\
\text { participans CFS }\end{array}$ & $90 \%$ & $10 \%$ & Very good \\
\hline \multirow[t]{3}{*}{4.} & $\begin{array}{l}\text { Instrument monitoring evaluating the } \\
\text { concept CFS. }\end{array}$ & $90 \%$ & $10 \%$ & Very good \\
\hline & Total & 370 & 370 & \\
\hline & Average & 90,10 & 90,10 & Very good \\
\hline
\end{tabular}


Based on table 3, the results of the second cycle of research in planning obtained by the following figure 3 .

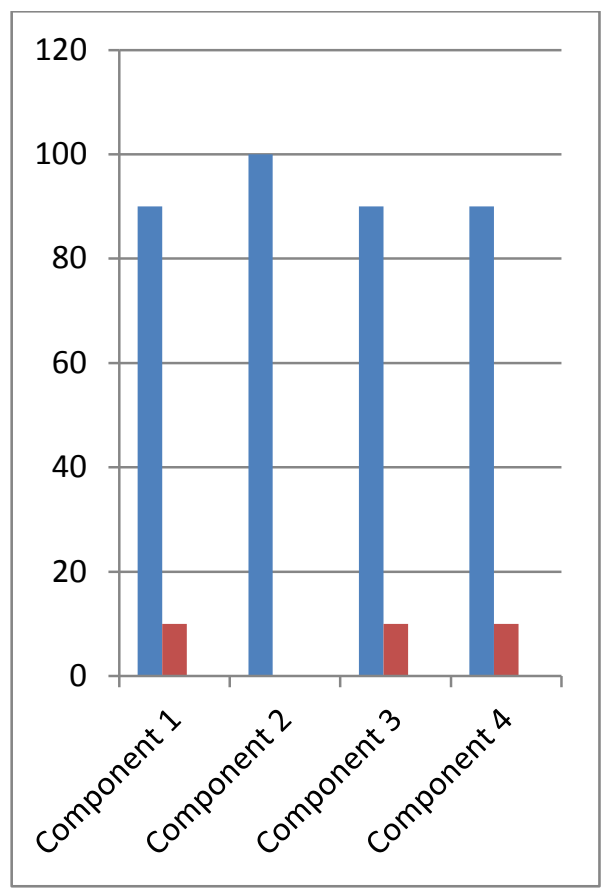

Figure 3. The Planning Of The Child Friendly School On Cycle 2

Graph Description:

Component 1 = Development planning the CFS

Component $2=$ A powerpoint the CFS

Component $3=$ Instrument of observation of the activation participans the CFS.

Component $4=$ Instrument of monitoring evaluating the growth the CFS.

Note: A (Very Good) $=86-100$

$\mathrm{B}(\mathrm{Good})=71-85$

$\mathrm{C}($ Enough $)=56-70$

$\mathrm{D}$ (Less) $=\leq 56$

\section{Action}

In the cycle 2, implementation, researchers consistently collaborated with The Team of Development the CFS to assist in the implementation the CFS through the models of 
GROW ME in accordance with the reviewed program plan, namely preliminary activities, core activities, and closing activities. The following is a description of the steps in assisting the implementation the CFS using the model of GROW ME.

In the preliminary activity, the activity begins with determining the Goals $(G)$ the purpose of implementing the CFS. First, the coachee discusses to determine the objectives of the implementation the CFS. The trainee / participant agreed that this session aims to make participants understand in the meaning the CFS, the CFS indicators, the CFS stages, and the CFS activities. Next the coach asks about goals, meanings, and indicators of success to the goal.

In the core activities, the first is the implementation of Reality (R), the activities are: (a) the coachee / participant evaluates himself about the implementation of the the CFS, how it is now after the first cycle has been accompanied, and why. (b) The Coach asks about the conditions and reasons, and the efforts that have been made. As stated by the Principal that the current conditions are related to the implementation of the CFS, the school has progressed in implementing the CFS. First, the school has socialized and implemented optimally the "Slogan" of the school as an area of Welcome To CFS. Furthermore, the school code of conduct was also refined about the things that must be done by the school community such as manners and things that should not be done such as tweaking, pinching, yelling. compare with other friends. Second, the school has carried out a variety of CFS activities such as (a) structured physical structuring, such as the arrangement of the school location, arrangement of the study room, arrangement of the laboratory room, arrangement of the library room, arrangement of the counseling room, arrangement of the happy corner where the child expresses himself, confide in, and playing with peers, structuring healthy canteen and honesty canteen, arranging trash cans, arranging toilet. (b) growing teachers and professionally trained/professional administration through In-House Training in a sustainable way. About the importance of implementing the CFS according to teacher class 4 that schools need to consciously endeavor to guarantee and fulfill children's rights through CFS based learning.

Second, the implementation of Options (O) -alternative. the activities are: (a) the coachee asks himself about solutions to achieve the objectives, according to Team of CFS there is a need for escort by theTeam of CFS which includes preparation of planning, implementation and monitoring and evaluation. Next the coach asks the learner to explore various other alternatives and offers suggestions carefully.

Third, the implementation of What's Next? / Will (W). In the implementation of What's Next? (W), the activities are: (1) The Coachee reveals alternative plans for solving the problem following the stages, as well as potential obstacles and solutions, as well as time allocation. Stages towards CFS include: First, Preparation, (a) it is necessary to continue to 
consult children to map the fulfillment of rights and to make recommendations made by the teacher class 5, (b) Principal, School Committee, Parents/guardians, and students are committed to implementing the CFS. This commitment takes the form of a CFS policy. (c) the Principal along with the School Committee, and students to form a CFS Development Team. The team is tasked with coordinating various efforts to develop CFS. (d) ongoing socialization of the importance of CFS; formulate and perfect and implement CFS plans, (e) monitor the CFS development process, (f) and evaluate CFS, (g) CFS Development Teams identify potentials, capacities, vulnerabilities, and threats in education units to developing CFS. Second, the planning includes the CFS Development Team to compile an annual action plan to create a CFS that is integrated in existing policies, programs and activities, such as the Advanced Environmental Cultivated School. Third, Implementation, the CFS Development Team carried out a revision of the annual CFS action plan by optimizing all resources in accordance with the plan. Fourth, monitoring evaluation is committed to be done quarterly, per semester,

Table 4. The Result of Monitoring Evaluation from Coach and Coachee In Implementation the Child Friendly School (CFS) The Cycle 2

\begin{tabular}{|c|c|c|c|c|}
\hline \multirow[t]{2}{*}{ No } & \multirow[t]{2}{*}{ Component } & \multicolumn{2}{|c|}{$\begin{array}{l}\text { Average } \\
\text { Achievement } \\
\text { Percentage } \\
\quad \%\end{array}$} & \multirow[t]{2}{*}{ Catagory } \\
\hline & & $\mathrm{Ya}$ & Tidak & \\
\hline 1. & The policies of school regarding CFS & $90 \%$ & $10 \%$ & Very good \\
\hline 2. & $\begin{array}{l}\text { The programs of health and facilities in education } \\
\text { units }\end{array}$ & $90 \%$ & $10 \%$ & Very good \\
\hline 3. & $\begin{array}{l}\text { The environment and infrastructure that are safe, } \\
\text { comfortable, healthy, and clean, as well as accessible } \\
\text { to meet } S N I \text { construction and buildings. }\end{array}$ & $95 \%$ & $5 \%$ & Very good \\
\hline 4. & The existence of child participation & $85 \%$ & $15 \%$ & Good \\
\hline 5. & The cultivation of noble values and cultural arts & $90 \%$ & $10 \%$ & Very good \\
\hline 6. & $\begin{array}{l}\text { The availability of trained educators and education } \\
\text { personnel }\end{array}$ & $90 \%$ & $10 \%$ & Very good \\
\hline 7. & The safety program in the education unit & $90 \%$ & $10 \%$ & Very good \\
\hline \multirow[t]{3}{*}{8.} & $\begin{array}{l}\text { The role of community and business participation in } \\
\text { the education unit }\end{array}$ & $90 \%$ & $10 \%$ & Very good \\
\hline & Total & 720 & 80 & \\
\hline & Average & 90 & & Very good \\
\hline
\end{tabular}


Note: A (Very Good) $=86-100$
$\mathrm{B}(\mathrm{Good})=71-85$
$\mathrm{C}($ Enough $)=56-70$
$\mathrm{D}($ Less $)=\leq 56$

Based on table 4 the results of monitoring evaluation of the coach and coachee about the growth of the Second Cycle the CFS, the picture is obtained through the following figure 4.

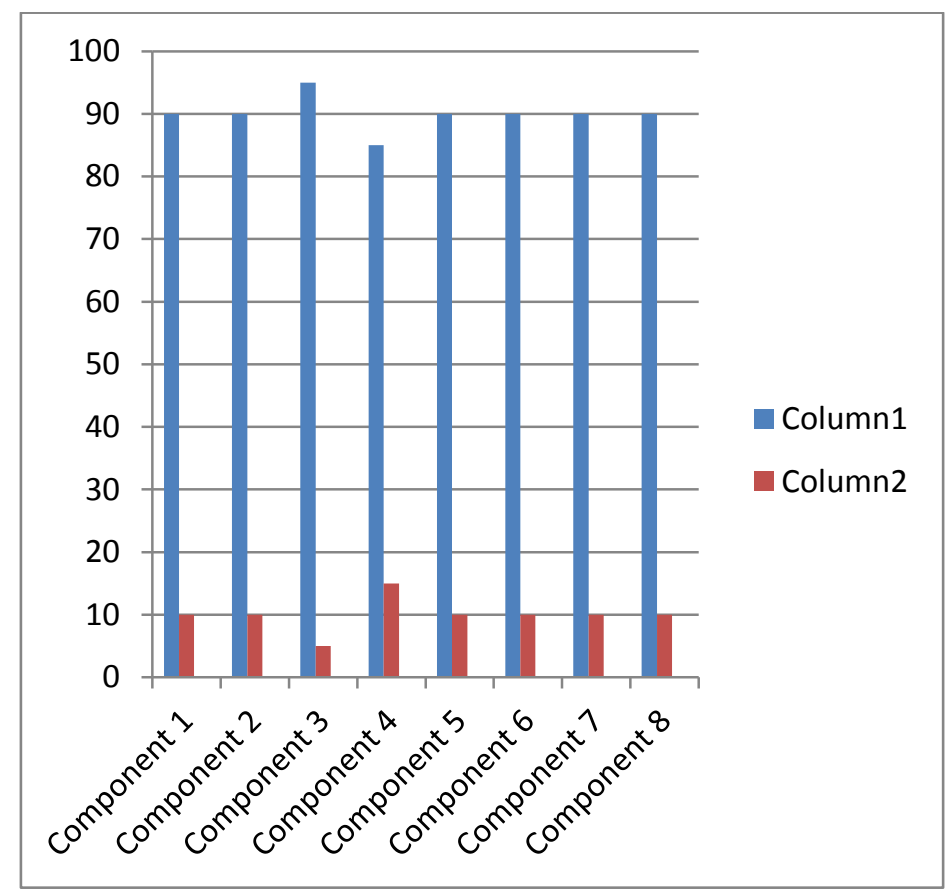

\section{Figure 4. The Result of Monitoring Evaluation from Coach and Coachee In Implementation the Child Friendly School (CFS) The Cycle 2}

Information:

Component 1 = The policies of school regarding CFS

Component $2=$ The programs of health and facilities in education units

Component 3 = The environment and infrastructure that are safe, comfortable, healthy, and clean, as well as accessible to meet $S N I$ construction and buildings.

Component $4=$ The existence of child participation

Component $5=$ The cultivation of noble values and cultural arts

Component $6=$ The availability of trained educators and education personnel 
Component $7=$ The safety program in the education unit

Component $8=$ The role of community and business participation in the education unit

\section{Observation}

The observation activities of the CFS mentoring program carried out by the observer / researcher/coach in collaboration with the CFS development team were aimed at various activation of the coachee / participant during the first cycle of mentoring activities.

Based on the observations during the second cycle of the CFS mentoring, the observer found that in general in the implementation of the CFS mentoring, some trainees/participants tend to be no longer awkward, active, responsive so that there has been a pleasant atmosphere of assistance (joyfull) for participant / coachee

\section{Reflection}

The results of reflection in the second cycle show that: (a) how to provide motivation for participants in the second cycle of assistance has varied. Optimum participant/coachee interest in the materials and processes of the CFS; (b) the coachee's performance in the CFS using the GROW ME model is optimal.

\section{Discussion of Research Results}

In this section the researcher will discuss and compare the results of the first cycle and second cycle research as follows.

1. Planning Child Friendly School (CFS) using the model of GROW ME in cycle 1, reaching an average of $80 \%$ and in second cycle an average of $90 \%$. This means that the planning of child-friendly school programs in the second cycle increases $10 \%$ or better than in the first cycle as shown in table 5 below.

Table 5. Comparison The Planning Achievements of Child Friendly School

Cycle 1 and Cycle 2

\begin{tabular}{llll}
\hline No & Component & Cycle 1 & Cycle 2 \\
\hline 1 & Plan & $80 \%$ & $90 \%$ \\
\hline
\end{tabular}


The comparison of the average scores of the planning components of Child-Friendly School in cycle 1 and cycle 2 can be seen in the following figure 5.

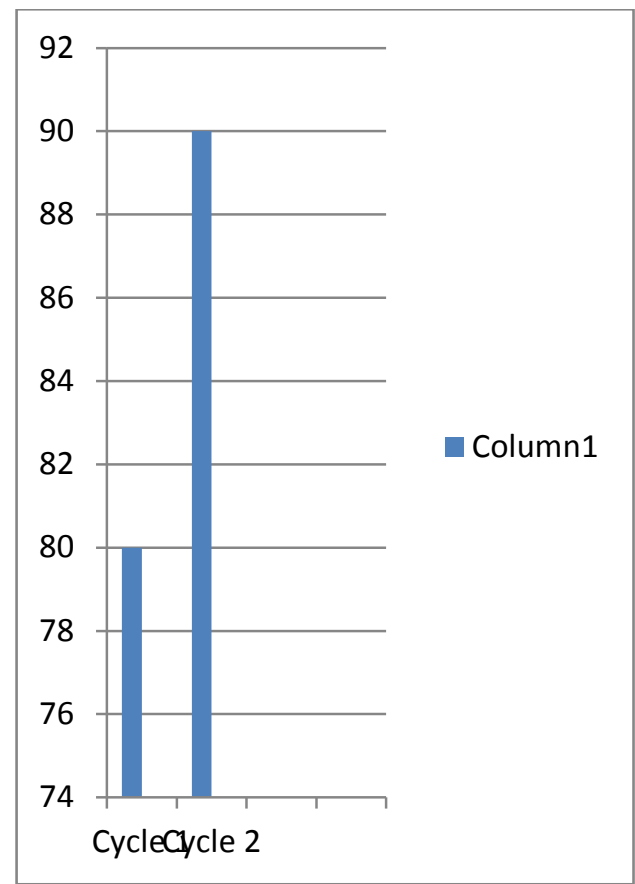

Figure 5. Comparison of average scores for Child Friendly School Planning

Cycle 1 and Cycle 2

The results of monitoring the evaluation of the implementation of the Child Friendly School, in the first cycle was $80.82 \%$ (good category) and in the second cycle it was $90 \%$ (very good category) or an increase of $9.12 \%$, as shown in table 6 below.

Table.6. Comparison of Monitoring Results the Implementation of Child Friendly School Cycle 1 and Cycle 2

\begin{tabular}{llll}
\hline No & Component & Cycle 1 & Cycle 2 \\
\hline 1 & Implementation of Child & $80,82 \%$ & $90,00 \%$ \\
& Friendly School & & \\
\end{tabular}


Comparison of average scores from the results of monitoring the evaluation of the implementation of the Child Friendly School can be seen in figure 6 below.

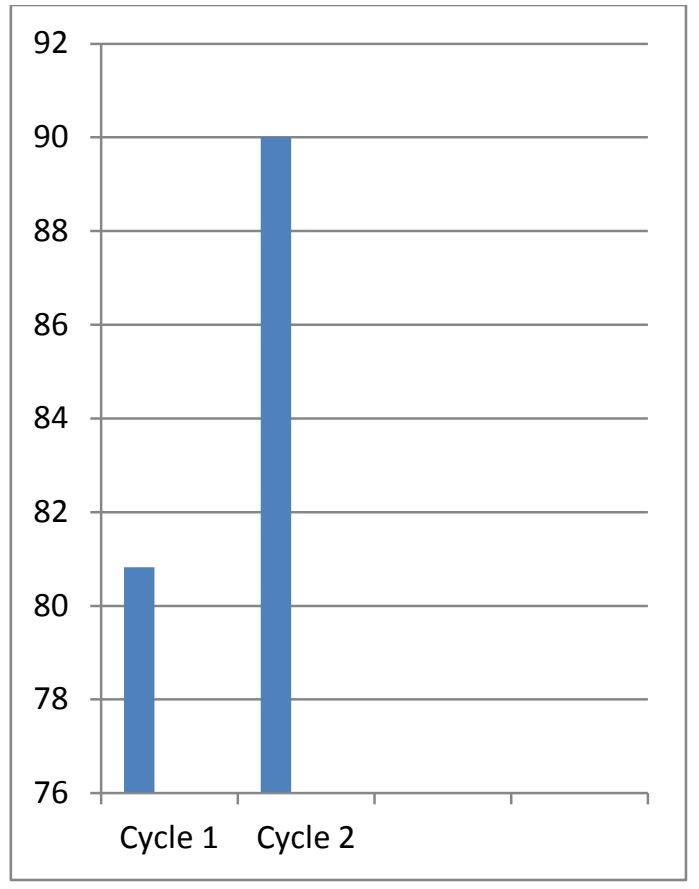

Figure 6. Comparison of Average Score from Monitoring Results Evaluation of Implementation of Child Friendly School in Cycle 1 and Cycle 2

Based on figures 5 and 6 above shows an increase in the implementation of CFS. This can be seen in the average overall score of the evaluation monitoring results in both the planning dimension and the dimensions of the implementation of CFS showing that in cycle 2 is higher than in cycle 1.

The success of CFS requires ongoing planning and implementation. The CFS planning components include: the development planning of CFS, The power point of CFS, the instrument of observation of the activation participans of the CFS, and the instrument of monitoring evaluating the growth of CFS. This is relevant to the result of study Ambarsari and Harun (2020: 2), that the CFS planning component include: doing socialization about fulfillment of rights and protection of children; giving the learner space to argue; mapping early school conditions; developing child friendly school policies in each school; and forming a child friendly school development team.

Furthermore, the implementation of CFS is also relevant to the results of the study Slam (2016) and Febriantina and Wijayanti (2018) that the development of CFS is seen in: (1) the policies of school regarding CFS; (2) the programs of health and facilities in education 
units; (3) the environment and infrastructure that are safe, comfortable, healthy, and clean, as well as accessible to meet SNI construction and buildings; (4) the existence of child participation; (5) the cultivation of noble values and cultural arts; (6) the availability of trained educators and education personnel; (7) the safety program in the education unit; and (8) the role of community and business participation in the education unit.

Therefore, the application of the model of GROW ME can effectively develop the CFS, this can be seen from the different results of the mentoring before and after the activities of developing the CFS.

In line with the results of Sarifudin's research (2018) that clinical supervision - GROW ME can improve the quality of the process and learning outcomes. This model can increase the activities, attitudes, attention of teachers and students. Clinical supervision-GROW ME is more effective than conventional clinical supervision. The research results of Amir et al (2015) conclude that the application of academic supervision of the GROW ME technique can improve the ability of English teachers in applying STAD type cooperative learning models.

The results of Arka et al (2015) showed that there were significant differences in the ability of teachers to manage integrated thematic learning between those supervised with the model of GROW ME and the directive approach. This means that the results of applying the model of GROW ME are better than the directive approach.

Based on the results of the research above shows that the application of the model of GROW ME in a variety of training shows better results than the directive approach. This success is because the model of GROW ME has a philosophy of professional development and is a tool to foster coaching and improve performance based on increasing self-awareness and personal responsibility. In addition, the model of GROW ME is a simple training method that focuses on goal setting and problem solving. The application of GROW ME is the key to success in a management process, because GROW ME brings people to always contribute and participate as active partners.

\section{CONCLUSIONS}

Based on the results of the discussion that has been described above, it can be concluded that after providing mentoring with the model of GROW ME, the results of the implementation of Child Friendly School (CFS) every cycle has increased. First, in cycle 1 the dimensions of planning child friendly school reached an average of $80 \%$ (good category). After an improvement in cycle 2, the results of planning child friendly school program experienced a significant increase with the average achievement of $90 \%$ (very good category). This means that the implementation of planning in cycle 2 increased $10 \%$ or better than in cycle 1. 
Secondly, in cycle 1 the dimensions of the implementation of child friendly school reached an average of $80.82 \%$ (good category). After an improvement in cycle 2 the results of the implementation of the child friendly school program experienced a significant increase with the average achievement of $90 \%$ (very good category). This means that the results of the implementation the Child Friendly School program in cycle 2 increased $9.12 \%$ or better than in cycle 1 .

\section{REFERENCES}

Ambarsari \& Harun (2018). Persiapan Perencanaan Sekolah Ramah Anak di SD Percontohan Yang Dipilih Oleh KPPPA. Yogyakarta: Universitas Negeri Yogyakarta

Akoto Mark (2013). The Concept Of Child Friendly School. [Online]. From: Retrieved February, 22th,2020

Amir at.al ( 2015).Penerapan Supervisi Akademik Teknik Pelatihan GROW ME Untuk Meningkatkan Kemampuan Guru Bahasa Inggris Menerapkan Model Kooperatif Tipe Skripsi. STAD. Medan. Unimed.

Arka, IK, Dkk (2015). Pengaruh Supervisi Akademik Model Coaching GROW ME terhadap Kemampuan Guru dalam Mengelola Pembelajaran Tematik Terpadu Setelah Mengontrol Konsep Diri pada Guru SD Gugus III dan IV Kecamatan Kuta Selatan Kabupaten Badung. Skripsi Undiska

Çobanoğlu, F. et.al (2018). Child-friendly Schools: An Assessment of Secondary Schools. Universal Journal of Educational Research. 6(3).p. 466-477.

Departemen Pendidikan Nasional (2009). Penelitian Tindakan Sekolah. Jakarta, Depdiknas.

Febriantina, \& Wijayanti (2018). Preparing Child-Friendly School Management. Journal Econosains. 16 (1), p. 76-83

Hermino, A. (2017 ). Child-Friendly School in Educational Settings for Elementary School in the Papua Island of Indonesia. Global Journal of Human Social Science : G Linguistics \& Education. 17 (1). p. 47-61.

Kementerian Pendidikan dan Kebudayaan (2013). Coaching: GROW ME Model. Jakarta, Kemendikbud.

Kementeritan Pendidikan dan Kebudayaan (2014). Prosedur Operasional Standar Penyelenggaraan Pelatihan Implementasi Kurikulum 2013 Untuk Pengawas Sekolah. Jakarta, Kemendikbud.

Kementerian Pendidikan dan Kebudayaan (2015). Sekolah Sehat. Ramah Anak dan Menyenangkan. Jakarta, Kemdikbud 
Kementerian Pendidikan dan Kebudayaan. (2016). Panduan Budi Pekerti. Jakarta, Kemendikbud.

Komisi Perlindungan Anak Indonesia. (2013). Peraturan Menteri Pendidikan dan Kebudayaan Nomor 82 Tabun 2015 Tentang Pencegahan dan Penanggulangan Tindak Kekerasan di Lingkungan Satuan Pendidikan.

Peraturan Menteri Negara Pemberdayaan Perempuan dan Perlindungan Anak Republik Indonesia Nomor 8 Tahun 2014.

Permata, A. (2017). Child-Friendly School And City For A Better Future. Semarang. Universitas Islam Sultan Agung

Slam, Z. (2016). Education Nonviolence Through Child Friendly School. Journal Of Education Of Muslim Society. 3 (2). p.187-204

Subur, at al. (2017). Implementasi Sekolah Ramah Anak Dalam Membentuk Budaya Sekolah Di SDN Geger Tegal Rejo. Konferensi asosiasi pascasarjama perguruan tinggi Muhammadiyah. Jakarta, Universitas Muhammadiyah Jakarta.

Tilaar. (2002). Perubahan Sosial san Kebudayaan. Jakarta, Grasindo

UNICEF. (2009). Schools as Protective Environments In Child Friendly School Manual. New

York, UNICEF

Undang-Undang Dasar Negara Republik Indonesia Tahun 1945

Undang-Undang Nomor 23 Tahun 2002 tentang Perlindungan Anak

Winataputera. (2012). Pendidikan Kewarganegaraan Dalam Perspektif Pendidikan Untuk Mencerdaskan Kehidupan Bangsa. Bandung, Widya Aksara Press

Wuryandani, at al. (2018). Implementasi Pemenuhan Hak Anak Melalui Sekolah Ramah Anak. Jurnal Civics: Jurnal Kajian Kewarganegaraan. 15 (1). p. 86-94. 